\title{
Water permit integration in the Paraguaçu River Watershed (Bahia)
}

\section{Integração de outorgas na bacia hidrográfica do rio Paraguaçu (Bahia)}

\author{
Gisele Oliveira Mota da Silva ${ }^{1}$, Yvonilde Dantas Pinto Medeiros ${ }^{1}$, Andrea Sousa Fontes ${ }^{2}$ and \\ Suzana Maria Gico Lima Montenegro ${ }^{3}$ \\ ${ }^{1}$ Universidade Federal da Bahia, Salvador, BA, Brazil \\ ${ }^{2}$ Universidade Federal do Recôncavo da Bahia, Cruz das Almas, BA, Brazil \\ ${ }^{3}$ Universidade Federal de Pernambuco, Recife, PE, Brazil \\ E-mails: gisele_oms@hotmail.com (GOMS),yvonilde.medeiros@gmail.com (YDPM), asfontes@gmail.com (ASF), suzanam.ufpe@gmail.com
} (SMGLM)

Received: September 01, 2016 - Revised: February 12, 2017 - Accepted: March 28, 2017

\begin{abstract}
In Brazil, water regulatory agencies adopt two different methodologies of equating water balance for the purposes of water permits: one that considers the uses for surface water withdrawal and waste water discharge in an integrated way, and one that analyses these two uses as demands that do not relate with each other. In the state of Bahia, this analysis disregards the integration of quantitative and qualitative uses. Furthermore, at the moment, there are not internal procedures that enable the integration of the water permit with other water resources management instruments. In this context, the aim of this work consists of analysing the advantages and limitations of the implementation of the equating methodology that integrates the quali-quantitative analysis of the water balance for purposes of water permit, compared with current procedures in the state of Bahia. For this analysis, a diagnosis of use of the Paraguaçu River Watershed (BHRP) was developed through the Water Balance Control System (SCBH), simulating the two methodologies and comparing potential water use index. The results reinforce that the methodology of equating the quali-quantitative water balance does not represent an advance for water resources management when the other instruments, present in the State Water Resources Policy, are not integrated with the water permit.
\end{abstract}

Keywords: Water resources management instruments; Water balance assessment; Water permit system.

\section{RESUMO}

No Brasil, os órgãos gestores de recursos hídricos adotam duas diferentes metodologias de equacionamento de balanço hídrico para fins de outorga de uso de recursos hídricos: a que considera os usos para captações superficiais e lançamento de efluentes de forma integrada e a que analisa estes dois usos como demandas que não se relacionam. No estado da Bahia, esta análise desconsidera a integração entre usos quantitativos e qualitativos. Além disso, no momento, não existem procedimentos internos que possibilitem a integração entre a outorga e os demais instrumentos de gestão de recursos hídricos. Nesse contexto, o objetivo do presente trabalho consiste em analisar as vantagens e limitações da implementação da metodologia de equacionamento que integra a análise quali-quantitativa do balanço hídrico para fins de outorga, comparada com os procedimentos vigentes no estado da Bahia. Para essa análise, foi realizado o diagnóstico de uso da bacia hidrográfica do rio Paraguaçu - BHRP obtido com o Sistema de Controle de Balanço Hídrico - SCBH simulando as duas metodologias e comparando indicadores de comprometimento hídrico. Os resultados reforçam que a metodologia de equacionamento de balanço hídrico quali-quantitativo não representa avanço na gestão de recursos hídricos quando os demais instrumentos da Política Estadual de Recursos Hídricos não funcionam de forma integrada com a outorga.

Palavras-chave: Instrumentos de gestão; Metodologia de equacionamento de balanço hídrico; Sistema de outorga. 


\section{INTRODUCTION}

Water is a natural resource that has environmental, social and economic importance. According to the National Water Resources Policy (BRASIL, 1997), water resources planning must be done in a decentralized way articulated with the user sectors, providing for multiple uses of water. This Legislation assigns to the Federal Executive Power to implement the PNRH and the National Water Resources Management System (Singreh) (SOUZA; MORAES, 2016).

According to Bezerra, Machado and Gomes (2015), the PNRH was characterized as an innovative policy for contemplating water through various approaches (decentralized, environmental, economic and social) and for recognising the multidisciplinary value of the water.

The water resources management model adopted by Brazil was developed based on scarcity and on conflicts provoked by various uses of water, with water resources policies that embrace management instruments such as the water permit and water charges, as a means of promoting its rational use (RODRIGUES; AQUINO; THOMAZ, 2015).

International experiences show some differences in water resources laws and their instruments. According to Wessling (2011), Germany's water management law, the Wasserbaushaltgesetz. (WHG), presents two instruments. The first one of them is "Bewilligung" (right of use), that normally refers to authorizations for water use by large companies with the character of public interest; the other is "Erlaubnis" (permission), being a water permit within shorter periods than the "Bewilligung" (under 15 years), conceded accordingly with established criteria depending on the use and is related, for the most part, to the permission of treated waste water discharge.

In the United States, there are differences in the characteristics of water use rights in function of the division of the country by the Mississipi River, into the eastern portion, with a humid climate, and the western, with a dry climate. In the eastern portion the riparian zones doctrine prevails, where water use is related to land ownership. The second doctrine, that is predominant in the western portion, is the "First in time is first in right" (prior appropXriation water system), where the priority of water use is established by the sequence in which the users benefit from this resource. There are states that do not adopt any of these doctrines, using a hybrid management model (WURBS, 1995). The United States has a history of institutional arrangement for water resources management which is formed by federal agencies and state agencies of control where the state historical presence is very strong (VEIGA; MAGRINI, 2013).

In Brazil, the effectuation of water permits must occur through the action of the competent authority in function of water dominance, according to the Federal Constitution of 1988 (BRASIL, 1988), in a manner that can be in function of the Union, the states or the Federal District.

The Union, the Federal District and the majority of states have water regulatory agencies with legal attributions to concede water permits. However, each agency has autonomy to determine their procedures, as well as legal and technical criteria to be adopted in the analysis of permits.
According to Pessoa, Kayser and Collischonn (2012), in the technical analysis of a water permit requirement, a comparison is made between water permit availability and demand, necessitating the use of network drainage data and spatial identification of users from the watershed.

Thus, in accordance with Silva, Silva and Moreira (2015), it is of fundamental importance that the water regulatory agencies have knowledge of water users in the basin and what those uses represent in terms of water availability compromise.

By means of the water permit, the managers can calculate the availability of water and the possibilities of water withdrawal in each water system. Also, they can calculate the required volume of flow of return to the water bodies, as well as the quality of waste water that can be discharged on the receiving water bodies (LEMOS; MAGALHÃES JUNIOR, 2015). Thereby, in the analysis of a requirement of water permit for surface water withdrawal, the requested withdrawal flow is compared with the water permit availability. Concerning waste water discharge, the conditions of the receiving water body are observed at the mixture point, respecting the established patterns for the framed class, as well as the patterns of waste water discharge. Both conditions must be in accordance with CONAMA $(2005,2011)$ in order for any new discharge to be authorized (PINHEIRO et al., 2013).

This study highlighted two different equating methodologies of water balance for purposes of water permit adopted by water regulatory agencies: one that considers the uses for surface water withdrawals and waste water discharge in an integrated way and one that analyses these two uses as demands that do not relate with each other. The determination of the water balance equating methodology between availability and demands to be used depends on the available resources (people, quality of input data, georeferenced hydrographic base, information system, etc.) the agency has with which to perform the water resources management.

The state water agencies of Bahia, Ceará, Espírito Santo, Goiás, Minas Gerais and Pernambuco adopt water balance equating methodologies between availability and demands that do not consider the interrelation between withdrawals and waste water discharges. Few are the states that use methodologies which consider the uses for surface water withdrawal and waste water discharge in an integrated way, such as the water agency of the Union, of the Federal District and of the states of Paraná and São Paulo.

The interrelation in the analysis of the water balance, considering withdrawals and discharges, happens in three moments: discharges upstream of withdrawals increase the availability of water for withdrawals; withdrawals upstream of discharges decrease the available flow for dilution; and, withdrawals downstream of discharges deduct part of discharged pollutants (COLLISCHONN, 2014).

Within the scope of the Water Resources Policy of the State of Bahia (PERH), the instruments of monitoring and inspection have little comprehensive data, the instruments watershed plans, the framework of water bodies in classes and the charge for use of the water have not been implemented, and, the State Environmental and Water Resources Information System (SEIA) is under construction. With the exception of the water permit, the other instruments have their information stored in specific support systems of the water agency of the state of Bahia, the Environmental and Water Resources Institute (INEMA), having 
no interrelation with the SEIA. Besides that, there are not internal procedures which make integration between instruments possible. This happening only informally between the Directors, Coordinators and board technicians in specific cases.

The need for interrelation between the instruments of water resources management instituted in the PERH of the state of Bahia can be verified in the analysis of a requirement of a water permit, which is made on legal, technical and social grounds. As regards the legal grounds, compliance with the current legislation is observed. For the technical analysis, the equating of the process is via the water balance, considering availability and demands. The availability is calculated with hydrological studies using historical series of flow data and or rainfall data and its efficiency is assured with the use of the instrument monitoring, since the water quantity and quality data are obtained from the monitoring of the water bodies. The management of demand comprehends water uses that have their efficiency ensured with the integrated use of instruments: SEIA; the inspection of water uses; the framework of water bodies in classes; the water permit; and, the charge for use of the water. As for the social character, it is represented by the analysis of water priority uses in the watershed, as defined with the population on the Watershed Plans.

INEMA adopts water balance equating methodology for technical analyses of water permit requirement, utilizing different systems that do not relate to each other, one referring to surface water withdrawals and the other regarding waste water discharges. These systems are named Water Permit Management System (SIGO) Withdrawal and SIGO Waste water.

The PNRH establishes that the dissociation of aspects of quantity and quality in the water balance system for water permits compromises the quali-quantitative control of water uses.

However, as presented, the absence of a consistent information system (SEIA) and the absence of comprehensive water resources inspection data, fluviometric monitoring data and water quality in the state of Bahia has been verified. Considering the analysis of requirement of water permit in a context that contemplates these limitations, an evaluation of the progress achieved in water resources management from the implementation of the equating methodology of water balance with quali-quantitative integration of water permit is necessary.

In this sense, the aim of this study was to analyse the advantages and limitations of the implementation of the qualiquantitative equating methodology of water balance for purposes of water permit in the study area, the Paraguaçu River Watershed (BHRP), totally inserted in the state of Bahia, contributing to the discussion of factors involved in the analysis of water permit requirement. These factors include the situation of the fluviometric monitoring of data, water quality and inspection, evidencing the interference on water use control and how the organization and integration of the PERH instruments can improve the instrument of water permit.

\section{WATER PERMIT IN THE STATE OF BAHIA}

Currently the emission of water permits in the state of Bahia is the responsibility of the Environmental and Water Resources Institute (INEMA), created through the Law No 12.212, of May $4^{\text {th }}$ of 2011 (BAHIA, 2011).
In order to implement the PERH, INEMA follows the guidelines of Bahia (2009), that also provides for the State Water Resources Management System and all the instruments of this Policy are managed by this management body.

Nonetheless, despite the PERH management instruments being distributed to Directories of the same management body, there are not procedures that integrate the actions related to them.

The water permit requirement analysis has the support of four systems: State Water Resources Information System (SEIRH-PROHIDROS), SEIA and Water Permit Control Management System - SIGO Withdrawal and SIGO Waste water. The other PERH instruments have their information stored in specific support systems regarding the activities they execute, having no interrelation with SEIA.

\section{MATERIAL AND METHODS}

For the execution of this study, it was necessary to determine the water availability for each stretch of the BHRP. Then, the existing water quality data (parameter DBO), for this watershed, was collected from the Monitora system website (INEMA). To determine the water demand in this basin, the data of conceded water permit for surface withdrawal and waste water discharge were searched on the SIGOs.

The basin diagnostics and their comparisons were made possible by the use of a quantitative and qualitative potential water use index and all the evaluations were made with the SCBH model simulating two water balance methodologies:

a) Methodology that considers the integration of uses for surface water withdrawals and waste water discharge - used by the National Water Agency (ANA) with the SCBH.

b) Methodology that disregards the integration of uses for surface water withdrawals and waste water discharges - used by INEMA with the SIGO Withdrawal and the SIGO Waste water.

\section{Study area}

The watershed chosen for the evaluation of the analysis methodologies was the Paraguaçu River Watershed (BHRP), considering the existence of a hydrographic base compatible with Otto Pfafstetter's codification, used by the $\mathrm{SCBH}$, the dimension and importance of this river basin for the state of Bahia and the amount of permitted water users in the catchment.

The BHRP integrates the Water Management and Planning Region (RPGA) of the Paraguaçu River, Region X, located entirely in Bahia's territory, in its central-western portion. This basin is considered the most important in the state and is situated between the parallels of $11^{\circ} 11^{\prime}$ to $13^{\circ} 42^{\prime}$ South and the meridians of $38^{\circ} 48^{\prime}$ to $42^{\circ} 07^{\prime}$ 'West. It encompasses an approximate area of $54,873 \mathrm{~km}^{2}$, settled by 79 cities with an approximate population of 1.7 million people, corresponding to $12.68 \%$ of the state's population (GENZ; TANAJURA; ARAÚJO, 2011; IBGE, 2010; BAHIA, 2003).

The predominant climate in this region is sub-humid to dry in more elevated areas and semi-arid in lower lands. In the area upstream of the Pedra do Cavalo Reservoir, in the Middle 
Paraguaçu region, there is predominance of crystalline formations and semi-arid climate. In the final stretch, a strong presence of crystalline formations can be observed with detrital covers and climate from humid to sub-humid (BAHIA, 2003).

According to Genz, Tanajura and Araújo (2011), this basin has distinctive characteristics regarding surface water potentialities presented in each of its stretches: the Upper Paraguaçu, the Middle Paraguaçu and the Lower Paraguaçu. The upper and middle stretches have low water potentialities, even though there are stretches with drought flow practically null. On the other hand, downstream of Pedra do Cavalo Dam, in the Lower Paraguaçu, there is a good water potentiality. From the drainage network of this catchment, the tributaries that excel are the ones from the left bank: the Capivari, the Peixe and the Jacuípe rivers.

In this basin, about $92 \%$ of the urban population have human supply, $91 \%$ of these supplies being from surface water bodies. The storage of water in reservoirs is a dominant system to supply all the purposes of water use in this basin, the most important reservoirs being: Apertado, Bandeira de Melo, França, São José do Jacuípe and Pedra do Cavalo. The importance of Pedra do Cavalo Dam is emphasised since approximately $60 \%$ of the water supply for the consumption of the metropolitan region of the state capital Salvador is from the lake formed by this dam (GENZ; TANAJURA; ARAÚJO, 2011; BAHIA, 2003).

The water use for waste water dilution is highlighted, because according to the latest update of the State Water Resources Plan, of the total organic load produced by household sewers, in this basin, $93 \%$ is destined to septic tanks, discharged on the soil or destined to the rainwater drainage network. Of the total household sewage collected $(7 \%), 3 \%$ is treated before being discharged in the water body (BAHIA, 2003).

Therefore, it is important to point out the precariousness of the sanitation services in the cities of this watershed, since, as presented, the majority of them do not have a sewage collection system and some of them have individual treatment systems, without the intervention of Public Power, concluding that most of the organic load generated has the water bodies as its destination, be it by the extravasation of cesspools, by waste water discharges in the drainage network or directly on the soil or in the rivers.

Thus, besides the uses regularized with the instrument of water permit, there are diffuse waste water releases, not accounted for in the water balance for purposes of water permit, weakening the water resources management executed by the State in this basin.

For this watershed, the only stretches where there is transitory framing were defined by the CONERH (2010), being: the Panela Stream, the Principal Stream, the Chapadinha River and the Paraguaçu River (downstream of the Pedra do Cavalo Dam).

\section{Characterization of the Water Permit Control Management System - SIGO (Bahia)}

According to Silva et al. (2003), the water permit control methodology by watershed using two Decision-making Support Systems - SADs (SIGO Withdrawal and SIGO Waste water) was conceived in the year 2000 and concluded in the beginning of 2003 in the extinct Water Resources Superintendence of Bahia
(SRH). An electronic Excel spreadsheet was developed and is still in use with some alterations.

Each main river of the Water Management and Planning Regions (RPGAs) has a SIGO. Silva et al. (2003) describe the physical basis of the system with the organization of the flux of the flows in the entire drainage network. The guideline of flow network is from the main river, from the river source to the river mouth. Then, from the source of the main river, each tributary is verified, and then the network design is constructed. On this network the control points, understood as the points of affluence of the main sub-tributaries of the main river, and the points of water permit are identified.

The main input data for the SIGOs are: water availability and water use demand. The water availability data are obtained from the analysis of historical flow data, the generation of flow duration curves and the flow regionalization. Flow data are extracted from inventory file, made available by ANA via the Hidroweb Hydrologic Information System. With this data, duration flows are calculated, and if required, flow regionalization studies are made. The obtained results are added to SIGO. The demand data refer to the geographic location of the withdrawal or release spots, the drainage area for the spot, the flow to be taken or discharged, the regime of withdrawal or release and the waste water characteristics, in case of discharge.

As any water withdrawal in the catchment will provoke a negative impact on water availability of the river, in each evaluation the system analyses all the spots already permitted, upstream or downstream, under penalty of compromising a particular spot previously made feasible (SANTANA et al., 2002).

According to established criteria in Bahia (2007a), stream withdrawal can be permitted up to $20 \%$ of the reference flow by user and up to $80 \%$ of the reference flow for a group of users in the stretch analysed. The reference flow adopted for surface river water withdrawals of ownership of the state of Bahia is the flow of $90 \%$ (Q90) of daily level.

The analysis of water permit requirement for waste water discharge is made using concepts of dilution flow and unavailable flow proposed by Kelman (1997).

According to Bahia (2007b), in the technical analysis for the emission of dilution, transport or final disposition water permits, the following parameters are evaluated: Biochemical Oxygen Demand (BOD) and Thermotolerant Coliforms in water bodies; Nitrogen and Phosphorus for environments subjected to eutrophication.

With the introduction of the characteristics of the waste water in the system, concerning the parameters above mentioned, the dilution flow is calculated for the final concentrations of parameters DBO and Thermotolerant Coliforms. For the fresh water river stretches that are not framed, they are considered as of Class 2, as determined by the art. 42 of Resolution n ${ }^{\circ} 357 / 05$ of the National Environmental Council (BRASIL, 2005).

According to Bahia (2007b), the reference flow adopted for dilution, transport or final disposition of waste water, except for estuarine areas and intermittent rivers, is one of $90 \%$ (ninety per cent) of daily level (Q90), the individual maximum limit being of $20 \%$ (twenty per cent) of the reference flow, and the sum of flows reserved for dilution, transport or final disposition of 
household waste water, for each analysis node, will be at maximum $50 \%$ of the Q90.

In the SIGO waste water, depuration calculus for DBO and Thermotolerant Coliforms are not made for the river stretches, the unavailable flow for new dilutions downstream of the spot of release being constant.

\section{Characterization of the Water Balance Control System - SCBH (Union)}

The Decision-making Support System (SAD), named Water Balance Control System (SCBH), was proposed by Collischonn and Lopes (2008) and it calculates the potential water use index and the water balance with the insertion of the new user integrating water surface withdrawal and waste water discharge.

SCBH was developed in two versions: in Matlab language and in PHP language with SQL Server database. For this work, the Matlab version was used, because its programing and manipulation were considered more accessible for the desired target.

The water balance between demands and water availability in the $\mathrm{SCBH}$ is made by river stretches. A stretch is a hydrographical feature situated between two confluences and each stretch corresponds to one single reference flow. Using this methodology, within the same stretch, it is not possible to distinguish which user is upstream and which is downstream. Everything develops as if all users were in the outlet point of the stretch. For a sufficiently dense hydrographic base, this discretization does not cause greater problems (COLLISCHONN, 2014).

The main input data for $\mathrm{SBCH}$ are the water availability data, the hydrographic base and the water demand use data. The demand data refer to the geographic location of the withdrawal spot or the discharge, the drainage area for the point, the flow to be collected or released, the regime of withdrawal or discharge and the waste water characteristics, in case of discharge.

$\mathrm{SCBH}$ allows the input of seasonal flow information (month after month) for water availability, this being one of its differentials compared with SIGO. This information is organised in an Excel spreadsheet with the attribution of twelve values of reference flow (one for each month) for each stretch of the hydrographic base used.

The hydrographic base for the development of the SCBH consists of a digital hydrography, normally in shapefile. This hydrographic base must be coded according to Otto Pfafstetter's methodology. According to Teixeira (2012), Otto Pfafstetter's basin codification organises the river stretches considering the relative position of basins and interbasins, enabling the identification of the position of a certain stretch according to its assigned code.

As presented by Collischonn (2014), this system also has a quali-quantitative interface, when it considers that water withdrawals withdraw DBO load from the river, in the same proportion that they take local water availability. This is the main difference in relation to the methodology adopted by the state of Bahia. The results of the system are expressed by the potential water use index., that refer to the relation between demands for surface water withdrawal or waste water dilution existing in the river stretches and their water availability. Thus, this index does not describe only how much water there is in the rivers, but the relation between what is available and how much it is being used. The formulation of the index was described by ANA (2013).

\section{Determination of water availability}

The water availability of the rivers of this catchment was calculated based on the historical series, determining the flow that endures for $90 \%$ of the time (Q90). The fluviometric stations chosen for the calculation of the Q90 are those currently used to calculate water availability for purposes of water permit by the state of Bahia, they are: ANDARAÍ (Code: 51120000), for the stretches of the Paraguaçu River situated upstream of Santo Antônio River and other not mentioned stretches; ITAETÉ (Code: 51240000), for the stretches of the Paraguaçu River located downstream of the Santo Antônio River and stretches of the Una River; FERTÉM (Code: 51190000), for the stretches of the Santo Antônio River; WAGNER (Code: 51158000), for the stretches of the Utinga River; BONITO (Code: 51166000), for the stretches of the Capivari and the Pratigi rivers; and, FRANÇA (Code: 51410000), for the stretches of the Jacuípe River. To minimize the influence of the existing uses in the watershed on determining the reference flow, most of the stations selected have flow data from 1935 to 1994, considering that in those years there was low interference due to water withdrawal or implantation of dams in the waterbodies.

To calculate the reference flow in the spots of analysis, the flow regionalization method was used from the specific flow of the chosen station (Qesp).

For the users with withdrawal or waste water discharge spots located downstream of the dams, the calculation for the reference flow was made by the sum of flow that goes downstream of the dam with the flow generated by the regionalization method, considering incremental drainage area from the dam to the spot.

Furthermore, from the dam stretch, the upstream demands were not considered, since, in terms of water balance, it was assumed that a new stream is formed in this stretch, interrupting the propagation of demands downstream.

Water availability in the stretches of the most important reservoirs of dam lakes of the basin was defined as the regulated flow by those dams. The information of regulated flow and the downstream flow was extracted from the documents present in the dam water permit processes (Technical Advice and Water Permit Ordinances). The stretches, that are in the flood area, were identified and their reference flow altered to the regulated flow.

For withdrawals taken in small private dams, the alteration of water availability due to flow regularization was not considered, the presence of dam being recorded for the simulation by the use of $20 \%$ of the Q90 for each dam, as though it was a surface stream withdrawal, since there is not available information about the flow that goes downstream and the regulated flow for the majority of users.

The main existing dams in the Paraguaçu River Basin and their more relevant characteristics are shown in Table 1.

Table 2 presents the equations used to calculate the Q90 considering the existence of a dam. Being: Q90esp, the relation between the Q90 and the drainage area of the station; Amon, the drainage area upstream of the calculated stretch; Abar, the drainage area upstream of the dam; and, Qjus, the flow that goes downstream of the dam. 
Table 1. Main existing dams - Paraguaçu River Basin.

\begin{tabular}{lcc}
\hline \multicolumn{1}{c}{ DAM } & REGULATED FLOW $\left(\mathbf{m}^{\mathbf{3}} \mathbf{s}\right)$ & DOWNSTREAM FLOW $\left(\mathbf{m}^{3} \mathbf{~} \mathbf{s}\right)$ \\
\hline APERTADO & 5.9 & 3.000 \\
FRANCA & 0.86 & 0.087 \\
SAO JOSE DO JACUIPE & 1.03 & 0.175 \\
PEDRA DO CAVALO & 69.0 & 3.000 \\
BANDEIRA DE MELO & No information & 7.765 \\
\hline
\end{tabular}

Table 2. Equations for the calculation of the Q90 considering the existence of dam.

\begin{tabular}{|c|c|}
\hline Equation to determine Q90 & River stretch \\
\hline $\mathrm{Q}_{00 \mathrm{jus}_{\mathrm{Ap}}}(1)=\mathrm{Q} 90 \mathrm{esp}(1) \cdot($ Amon $-\mathrm{Abar})+\mathrm{Qjus}$ & Downstream of Apertado Dam and upstream of the confluence with Santo Antônio River \\
\hline $\mathrm{Q} 90 \mathrm{jus}_{\mathrm{Ap}}(2)=\mathrm{Q} 90 \mathrm{esp}(2) \cdot($ Amon $-\mathrm{Abar})+$ Qjus & Downstream of Apertado Dam and downstream of the confluence with Santo Antônio River \\
\hline $\mathrm{Q} \mathrm{jus}_{\mathrm{BM}}=\mathrm{Q} 90 \mathrm{esp}(3) \cdot($ Amon - Abar $)+$ Qjus & Downstream of Bandeira de Melo Dam \\
\hline $\mathrm{Q} 90 \mathrm{jus}_{\mathrm{PC}}=\mathrm{Q} 90 \mathrm{esp}(4) \cdot($ Amon $-\mathrm{Abar})+\mathrm{Qjus}$ & Downstream of Pedra do Cavalo Dam \\
\hline $\mathrm{Q} \mathrm{jus}_{\mathrm{Fr}}=\mathrm{Q} 90 \mathrm{esp}(5) \cdot($ Amon - Abar $)+\mathrm{Qjus}$ & Downstream of França Dam \\
\hline $\mathrm{Q} 9 \mathrm{jus}_{\mathrm{SJJ}}=\mathrm{Q} 90 \mathrm{esp}(6) \cdot($ Amon - Abar $)+$ Qjus & Downstream of São José do Jacuípe Dam \\
\hline
\end{tabular}

\section{Data collection of water quality monitoring spots for the parameter DBO}

Data for water quality were collected in the Monitora System for comparison with the qualitative potential water use index obtained with the water permit data.

According to Bahia (2007b), in places that are not subjected to eutrophication, for the analyses of water permit for waste water discharge, in the state of Bahia, the parameters evaluated are DBO and Thermotolerant Coliforms. However, as presented on the description of the $\mathrm{SCBH}$, it can evaluate the parameters temperature and $\mathrm{DBO}$ in places that are not subjected to eutrophication. So, SCBH does not calculate quantitative and qualitative potential water use index considering the concentration of Thermotolerant Coliforms, thus, only the existing monitoring data for DBO concentration were considered.

All sampling spots of qualitative data in the Paraguaçu River Watershed were searched and the viewed data were extracted to a table with the information:
a) Monitoring spot code;
b) city;
c) coordinates;
d) dates of developed field campaigns;
e) DBO concentration in $\mathrm{mg} / \mathrm{L}$.

56 monitoring spots with DBO concentration data were identified in the BHRP referent to sampling campaigns made since 2008 to 2016.

\section{Determination of water demand}

The data for the conceded water permits between 08/25/1999 and 04/25/2015 were extracted from the Water Permit Control Management System - SIGO Withdrawal and SIGO Waste water of the Paraguaçu River Watershed. The following data were listed for each spot for withdrawal and discharge:

a) coordinates of the water permit spot;

b) river stretch code (extracted from the ottocoded shape of the basin) where the water permit spot is located;

c) flow of withdrawal or of discharge;

d) purpose of water use or type of waste water;

e) for waste water discharge, DBO5 concentration of the final waste water;

f) status of the Water Permit Ordinance (valid or expired).

\section{Evaluation of the current water balance in the Paraguaçu River Watershed with SCBH support}

The diagnosis of the basin was possible with the use of the results obtained with SCBH: the potential water use index, that represent the relations between water demands and water availability. To compare the results considering the integration of quantitative and qualitative demands (methodology used on the SIGOs), tests were also made with the SCBH disregarding the integration, excluding withdrawals, and, then, excluding waste water discharges. The following diagnostics were generated:

a) BHRP qualitative and quantitative diagnostics with demand data for withdrawal and waste water discharge;

b) BHRP qualitative and quantitative diagnostics with only withdrawals demand data;

c) BHRP qualitative and quantitative diagnostics with only releases demand data.

In this study, a classification of the Quantitative and qualitative potential water use index was proposed, which is presented in Chart 1. 
This classification was used so that, in view of the compromise indexes values generated, the comparison with the maximum permitted values for water permit purposes for the quantitative and qualitative potential water use index in the state of Bahia was evidenced. The maximum permitted values are: a) maximum of $80 \%$ for the quantitative potential water use index (BAHIA, 2007a); b) maximum of $5 \mathrm{mg} / \mathrm{L}$ for the qualitative potential water use index (DBOsim) (BAHIA, 2007b; BRASIL, 2005).

After the result of the qualitative diagnosis for the watershed, the stretches of higher compromise were verified and comparisons were made with the existing monitoring data for those stretches.

\section{RESULTS AND DISCUSSION}

\section{Water availability for the Paraguaçu River Basin}

The main characteristics of the stations of reference used are presented in Table 3, along with the reference flows for purposes of water permit.

Figure 1 presents the results of water availability for the stretches of the BHRP.
With this result, it is possible to observe that the places where there is lower water availability are those stretches located in the Middle Paraguaçu, a semiarid climate region. The data used to calculate the $\mathrm{Q} 90$ of the $\mathrm{BHRP}$ river stretches, where there are dams, are presented in Table 4.

\section{Water demand for the Paraguaçu River Watershed}

Figure 2 exhibits the location of the water-permitted users in the Paraguaçu River Watershed. In this basin, regarding surface water withdrawal, the purposes of use are: $87 \%$ for irrigation, with an irrigated area of 36,640.00 ha; 10\% for human supply; and, $4 \%$ for industrial supply. As for dam withdrawals: $76 \%$ for irrigation, with an irrigated area of $8,913.00 \mathrm{ha} ; 12 \%$ for human supply; and, 11\% for industrial supply. Concerning waste water discharge: $85 \%$ are domestic waste water and $15 \%$ are industrial waste water.

By researching the water permit ordinances present in the SIGOs, the following information was extracted:

Chart 1. Classification of the potential water use index.

\begin{tabular}{|c|c|c|}
\hline Classification & Quantitative Index (Iquant) (\%) & Qualitative Index (DBOsim) (mg/L) \\
\hline LOW & $0<$ Iquant $<25$ & $1.0<$ DBOsim $<1.5$ \\
\hline MODERATE & $25 \%<$ Iquant $<50$ & $1.5<$ DBOsim $<3.5$ \\
\hline ALERT & $50 \%<$ Iquant $<80$ & $3.5<$ DBOsim $<4.9$ \\
\hline CRITICAL & $80 \%<$ Iquant $<100$ & DBOsim $=5.0$ \\
\hline HIGHLY CRITICAL & Iquant $>100$ & DBOsim $>5.0$ \\
\hline
\end{tabular}

Table 3. Fluviometric station data and reference flows.

\begin{tabular}{cccccc}
\hline CODE & NAME & RIVER & $\begin{array}{c}\text { Drain. Area } \\
\left(\mathbf{k m}^{2}\right)\end{array}$ & $\begin{array}{c}\text { Q90 } \\
\left(\mathbf{m}^{3} / \mathbf{s}\right)\end{array}$ & $\begin{array}{c}\text { Q90esp } \\
\left(\mathbf{m}^{3} / \mathbf{s .} \mathbf{k m}^{2}\right)\end{array}$ \\
\hline 51190000 & FERTÉM & SANTO ANTONIO & 9,670 & 5.22 & $5.4 \times 10^{-4}$ \\
51158000 & WAGNER & UTINGA & 1,320 & 1.40 & $1.1 \times 10^{-4}$ \\
51240000 & ITAETE & PARAGUAÇU & 16,500 & 9.28 & $5.6 \times 10^{-4}$ \\
51166000 & BONITO & BONITO & 731 & 0.61 & $8.3 \times 10^{-4}$ \\
51410000 & FRANÇA & JACUÍPE & 2,070 & 0.11 & $5.2 \times 10^{-5}$ \\
51120000 & ANDARAÍ & PARAGUAÇU & 2,350 & 2.11 & $8.9 \times 10^{-4}$ \\
\hline
\end{tabular}

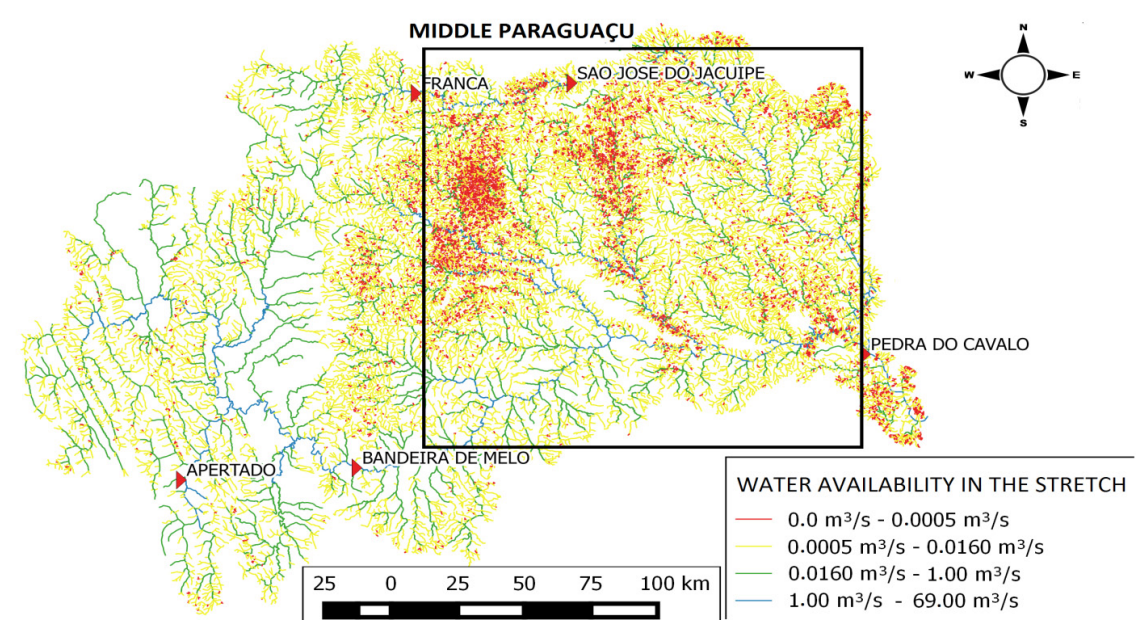

Figure 1. Water availability in the Paraguaçu River Watershed. 


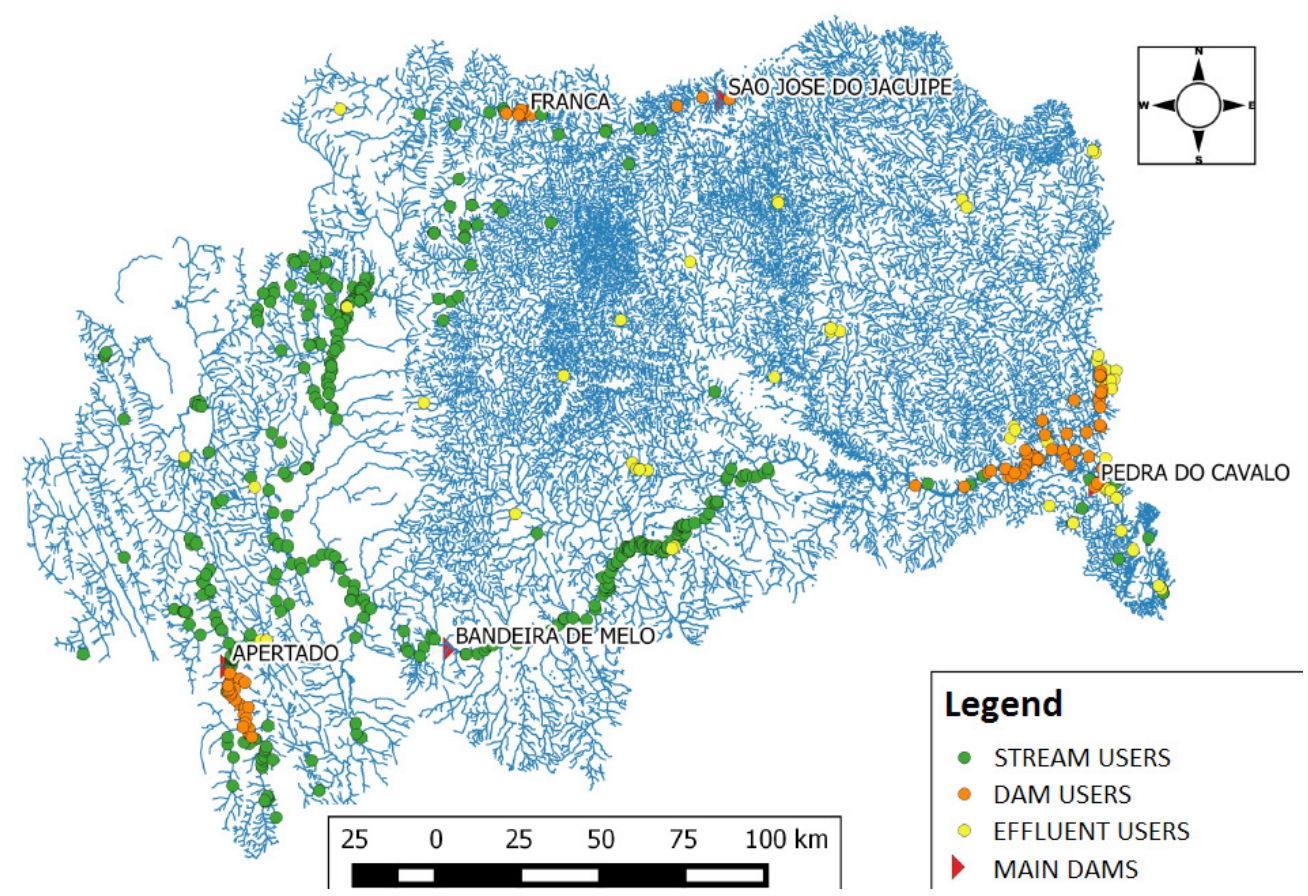

Figure 2. Permitted water users in the Paraguaçu River Watershed.

Table 4. Data used to calculate the Q90 of the stretches.

\begin{tabular}{cccc}
\hline Qesp IDENTIFICATION & $\begin{array}{c}\text { Q90esp } \\
\left(\mathbf{m}^{3} / \mathbf{s .} \mathbf{K m}^{2}\right)\end{array}$ & $\begin{array}{c}\text { DRAINAGE AREA } \\
\left(\mathbf{K m}^{2}\right)\end{array}$ & $\begin{array}{c}\text { DOWNSTREAM FLOW } \\
\left(\mathbf{m}^{3} / \mathbf{s}\right)\end{array}$ \\
\hline Q90esp(1) & $8.38 \times 10^{-4}$ & $1,162.00$ & 3.00 \\
\hline Q90esp(2) & $5.13 \times 10^{-4}$ & $17,400.00$ & 7.76 \\
\hline Q90esp(3) & $5.13 \times 10^{-4}$ & $56,475.04$ & 3.00 \\
\hline Q90esp(4) & $5.13 \times 10^{-4}$ & $2,117.53$ & 0.09 \\
\hline Q90esp(5) & $5.22 \times 10^{-5}$ & $4,490.62$ & 0.18 \\
\hline Q90esp(6) & $5.22 \times 10^{-5}$ & \\
\hline
\end{tabular}

a) Of the water permits for surface river water withdrawal, $11 \%$ of the conceded water permits have valid Ordinances, whereas, for surface dam withdrawal, $44 \%$ of them are valid.

b) Of the water permits for waste water discharge, $56 \%$ of the conceded water permits have valid Ordinances.

Thus, considering that the majority of users that do not have a valid water permit anymore keep using the water, to compare the analysis methodologies used in the SIGO and in the SCBH, all the conceded water permits (valid and expired) will be considered.

\section{Water Balance in the Paraguaçu River with quali-quantitative integration with $\mathrm{SCBH}$ support}

Simulation using SCBH was made and the results of quantitative index were obtained for the Paraguaçu River water balance. In this catchment, there are 28,544 river stretches ( $95 \%$ of total stretches) without use of water or with use for lower withdrawals compared to the use for waste water discharge, implying that there is not a high quantitative compromise of flow with the use. Considering only the stretches where there is quantitative compromise (1,699 stretches), the data obtained for quantitative potential water use index are presented in Table 5.

Once the shape was generated by the $\mathrm{SCBH}$, a map was elaborated showing the quantitative compromises of the Paraguaçu River stretches (Figure 3). The data presented in Table 6, illustrated with Figure 3, show that, of the 1,699 stretches where there are surface water withdrawal users and waste water discharge users of the Paraguaçu River, its majority (1,382 stretches) has low compromise.

However, it is possible to verify the high compromise in stretches located in the Upper Paraguaçu (Figure 4). This is a region of river sources and because of that it presents less availability of stream water and spots with regulated flow caused by dams. There is also a large demand for irrigation: in this region, there are various agricultural enterprises forming the Mucugê/Ibicoara Agropolo. Moreover, stretches where the demand approximates 
or exceeds water permit availability were verified in the city of Utinga, also located in the Upper Paraguaçu.

For the Lower Paraguaçu, there are stretches with critical quantitative potential water use index regarding withdrawals for human supply (Figure 5).

In the Middle Paraguaçu, stretches with critical conditions were not identified, because, even though there is low water availability in the tributaries, there are not recorded demands. For the main river, the flow is sufficient to supply the demands, configuring low quantitative potential water use index.

Considering the result for the stretches where a quantitative potential water use index greater than or equal to 1 (1,267 stretches) is verified, Table 6 was elaborated and it presents the Qualitative potential water use index (DBOsim) for the BHRP stretches.

To compare the results obtained with the qualitative potential water use index and the monitoring results extracted from the Monitoring System, the stretches that have the greater

Table 5. Quantitative potential water use index of the BHRP river stretches with quali-quantitative integration.

\begin{tabular}{cccc}
\hline \multicolumn{2}{c}{ QUANTITATIVE INDEX } & \multicolumn{2}{c}{ STRETCHES } \\
\hline LOW & $0 \%-25 \%$ & 1382 & $81 \%$ \\
MODERATE & $25 \%-50 \%$ & 102 & $6 \%$ \\
ALERT & $50 \%-80 \%$ & 125 & $7 \%$ \\
CRITICAL & $80 \%-100 \%$ & 26 & $2 \%$ \\
HIGHLY CRITICAL & $>100 \%$ & 64 & $4 \%$ \\
\hline
\end{tabular}

qualitative compromise were verified. The selected stretches were those with highly critical compromise (above $5.00 \mathrm{mg} / \mathrm{L}$ ). Figure 6 exhibits the values of qualitative compromise represented by the DBOsim (qualitative index generated by the $\mathrm{SCBH}$ ) for stretches of the Paraguaçu River and identifies the monitoring spots near the critical stretches.

With the data presented in Figure 6 and in Table 6, it is possible to notice that, of the 1,267 stretches where there are waste water discharge users in the Paraguaçu River, its majority (847 stretches) has low compromise.

On the simulation, it was verified that the majority of river stretches of the basin present LOW qualitative compromise, except for the stretches indicated in black, where the values of concentrations surpass the limits established for Class 2 rivers of CONAMA (2005), for the parameter DBO. Only three monitoring spots were identified that are located in river stretches of high compromise, those being: PRG-PRN-300, PRG-MAI-100 and PRG-MAI-200. All of these spots are situated in the city of Feira de Santana, in the Jacuípe River (Figure 7). The results of the monitoring campaigns for spot PRG-PRN-300, concerning the parameter DBO in $\mathrm{mg} / \mathrm{L}$, were $85.00 \mathrm{mg} / \mathrm{L}$ for the maximum value and $6.60 \mathrm{mg} / \mathrm{L}$ for the minimum value. According to the Monitoring System data, this river stretch has concentration values of DBO above the allowed concentration for Class 2 rivers. Still, none of the values obtained from the field campaigns that happened between the years of 2009 and 2015 reach the value found for

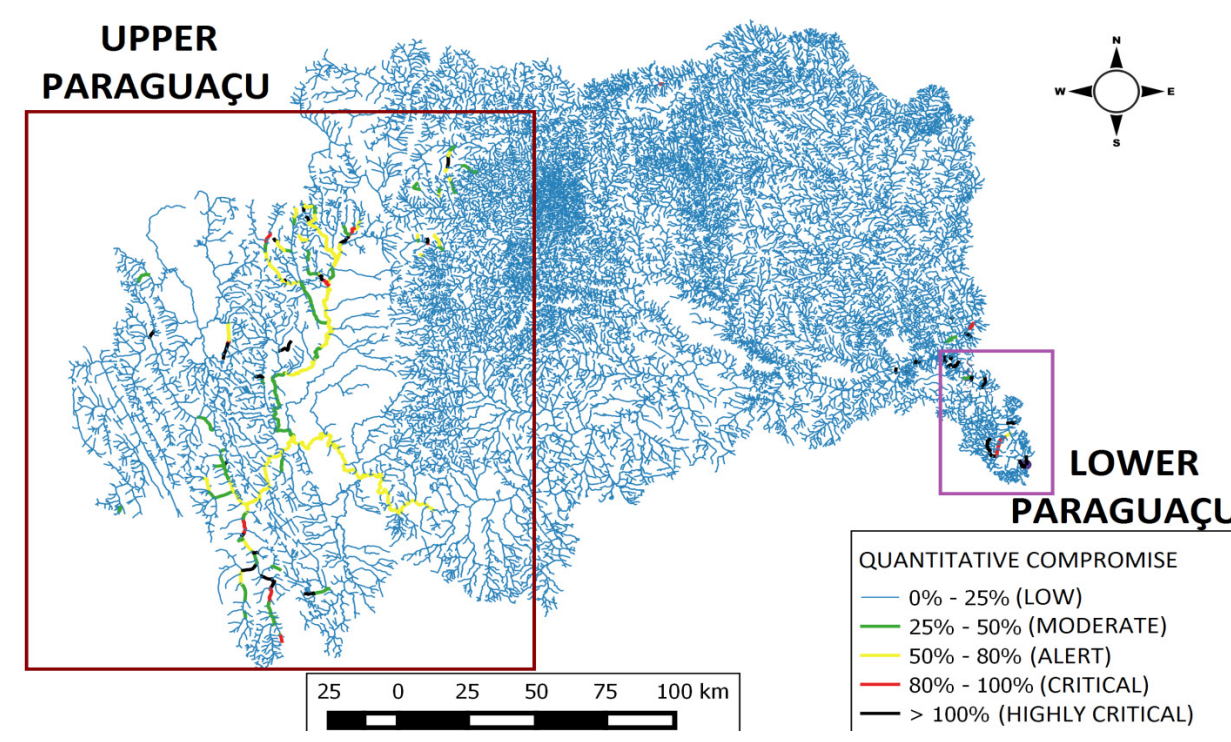

Figure 3. Quantitative potential water use index of the BHRP stretches with quali-quantitative integration.

Table 6. Qualitative potential water use index (DBOsim) of the BHRP river stretches.

\begin{tabular}{cccc}
\hline \multicolumn{2}{c}{ QUALITATIVE INDEX } & STRETCHES \\
\hline LOW & $1.0 \mathrm{mg} / \mathrm{L}-1.5 \mathrm{mg} / \mathrm{L}$ & 847 & $66.85 \%$ \\
MODERATE & $1.5 \mathrm{mg} / \mathrm{L}-3.5 \mathrm{mg} / \mathrm{L}$ & 259 & $20.44 \%$ \\
ALERT & $3.5 \mathrm{mg} / \mathrm{L}-4.9 \mathrm{mg} / \mathrm{L}$ & 29 & $2.29 \%$ \\
CRITICAL & $=5 \mathrm{mg} / \mathrm{L}$ & 0 & $0.00 \%$ \\
HIGHLY CRITICAL & $>5 \mathrm{mg} / \mathrm{L}$ & 132 & $10.42 \%$ \\
\hline
\end{tabular}




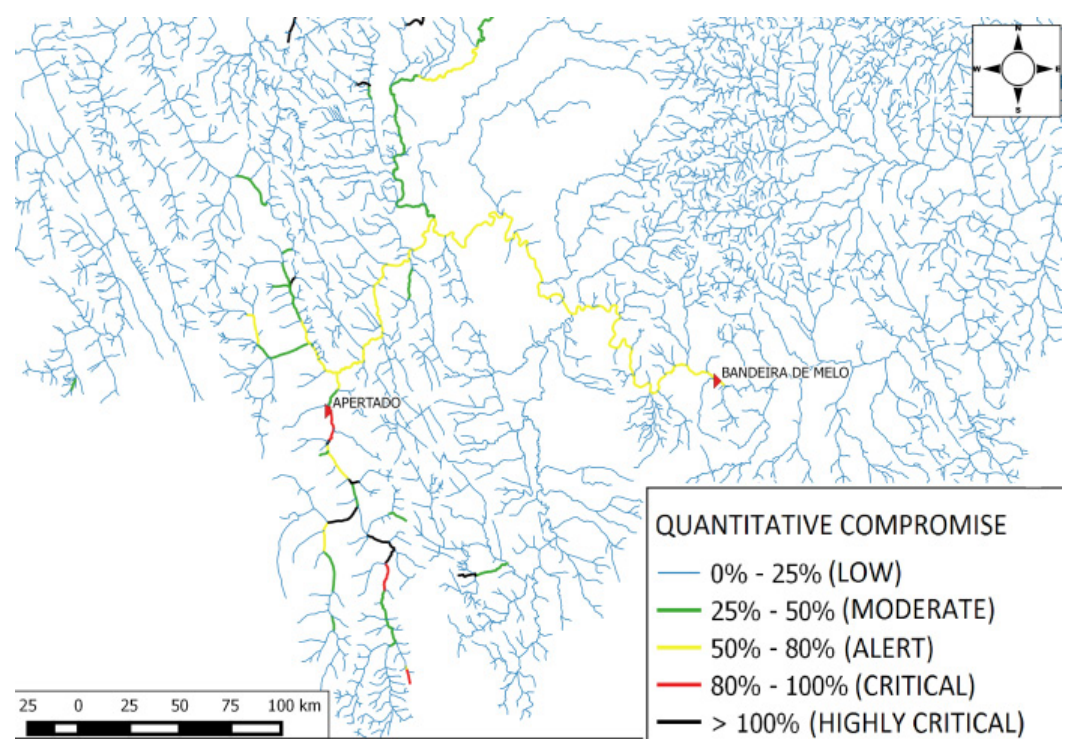

Figure 4. Quantitative potential water use index - Upper Paraguaçu with the integration of withdrawal and discharge.

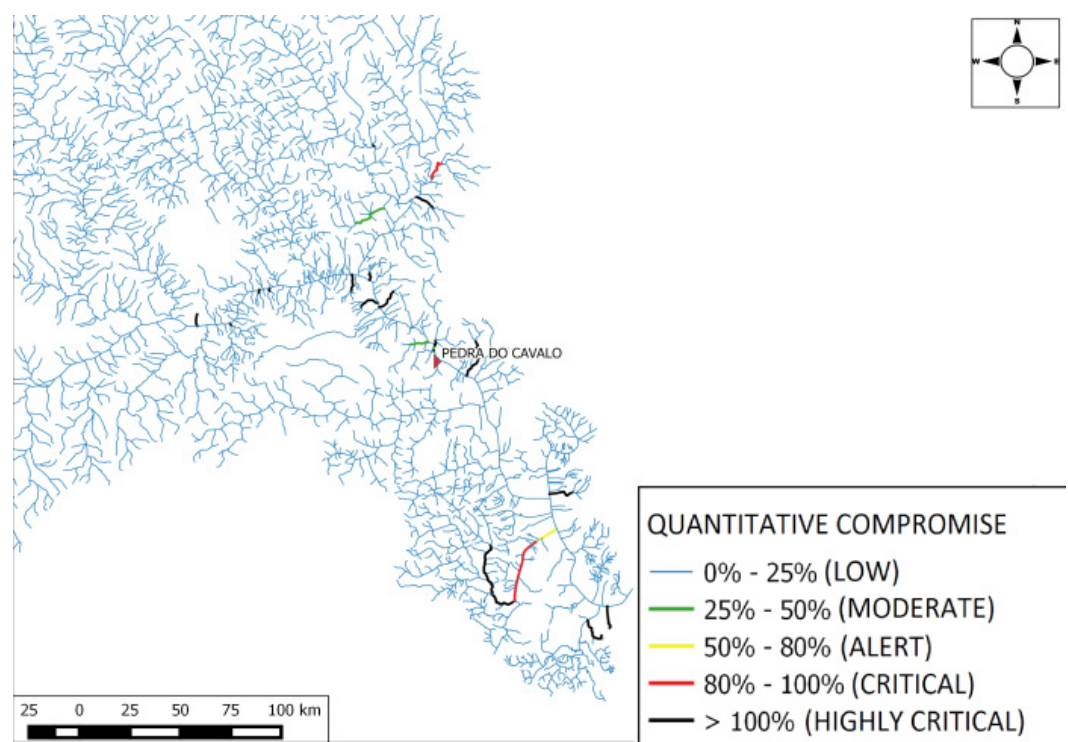

Figure 5. Quantitative potential water use index - Lower Paraguaçu with the integration of withdrawal and discharge.

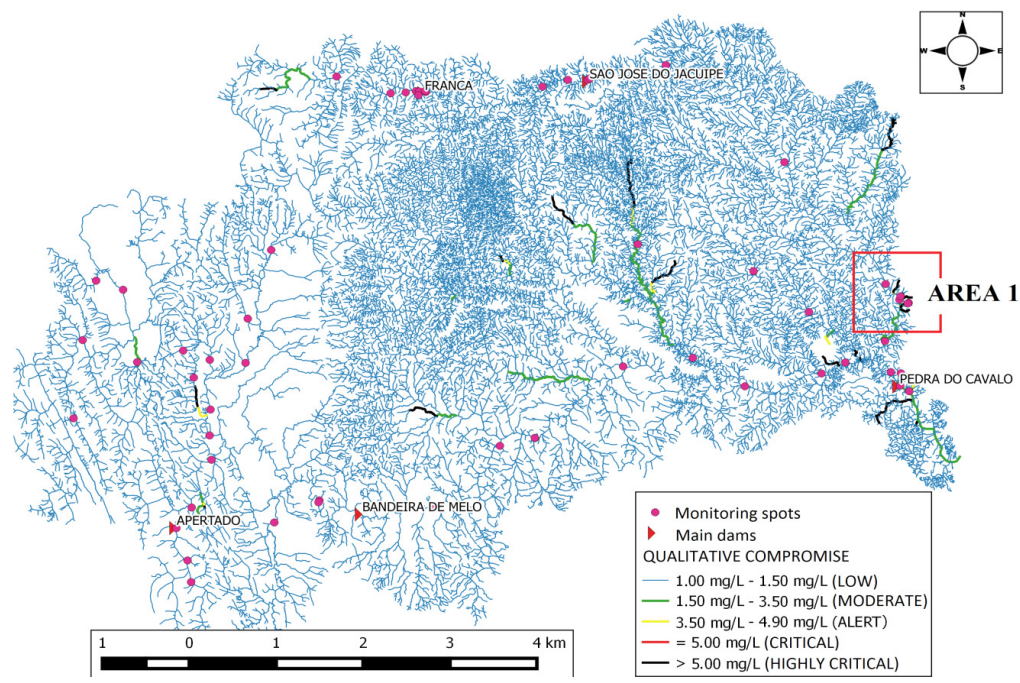

Figure 6. Qualitative potential water use index (DBOsim) in the BHRP with the integration of withdrawal and discharge. 


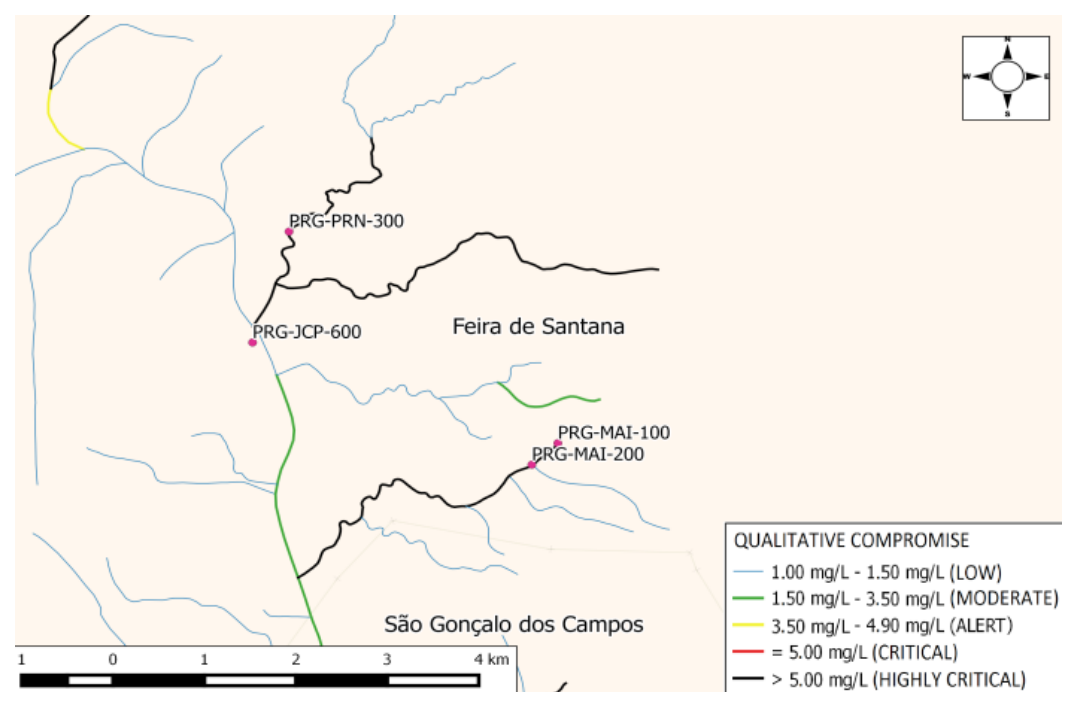

Figure 7. Monitoring spots in river stretches with highly critical DBOsim (AREA 1).

DBOsim in the stretch $(313.30 \mathrm{mg} / \mathrm{L})$, the maximum value being $85.00 \mathrm{mg} / \mathrm{L}$ obtained on the campaign of October $30^{\text {th }}$ of 2012.

There are no records of alteration of this water permit with the improvement of treatment, which highlights the need for inspection to verify if there was a change in the use for waste water discharge or if there is inconsistency in the data recording of the Monitoring System. Despite the environmental body periodically monitoring the stretch where the discharge occurs, the supervision of this water permit must occur, in the sense that deadlines and targets must be established, in order to improve the treatment, and the technical and legal requisites be achieved, since, as is presented in CONAMA (2011), this exceptional discharge must only occur temporarily.

In the stretches where the monitoring spots PRG-MAI-100 and PRG-MAI-200 are located, the DBOsim values obtained from the conceded water permit are $206.10 \mathrm{mg} / \mathrm{L}$ and $111.04 \mathrm{mg} / \mathrm{L}$, respectively. There is one authorized user for industrial waste water discharges in this river stretch that discharges waste water with DBO concentration equal to the concentration limit for the river class (class 2), but discharges a high value of waste water discharge $\left(159.16 \mathrm{~m}^{3} / \mathrm{h}\right)$, the organic load from this release being 40 times superior in relation to the permitted organic load for this water permit typology (BAHIA, 2007b). In those spots, the campaign data from the Monitoring System do not match with those found for DBOsim in the stretches analysed, because the values for DBOsim were lower than those indicated by Monitoring. The maximum value observed in all the monitoring campaigns was $39.3 \mathrm{mg} / \mathrm{L}$, while the DBOsim value was $206.1 \mathrm{mg} / \mathrm{L}$. Besides these stretches, monitoring points where high values for DBO were recorded were also verified. Those values were compared to the diagnosis results generated by SCBH. In these stretches, permitted water demands for waste water discharges were not identified. For the cases where there were identified stretches with high values of DBOsim and without record of regular waste water discharge users, the probable cause for the elevated value of DBO is the irregular and diffuse release of household waste water, as no water permit for waste water discharge from the nearby cities was identified. For the other cases, where there are records of waste water release and the $\mathrm{DBO}$ concentration values verified on the monitoring campaigns are greater than the values of DBOsim obtained with the simulation with $\mathrm{SCBH}$, besides making it necessary to verify the efficiency of the monitoring, there might be other non-authorized discharges or authorized releases that are not obeying the minimum efficiency of DBO removal recommended in the Water Permit Ordinance. In both cases, the need to make inspection in the location to identify and mitigate the motive of irregularity is verified.

In terms of quantitative monitoring, there are 56 spots in the BHRP with data for campaigns made between 2008 and 2015, corresponding to $0.2 \%$ of the amount of existing river stretches in the catchment, this being insufficient to generate representative information for the basin.

As it is possible to notice, the instruments of water permit, inspection and monitoring are strongly interrelated. In order to have efficient water resources management and to meet its objectives, their fortification and integration are of fundamental importance. Furthermore, it is evident that, besides an equating methodology of the water balance that represents results closer to reality, the incorporation of data obtained in the field is required. The greater the quantity and the quality of the input data of a system, the better are the results.

\section{Water Balance in the Paraguaçu River without quali-quantitative integration with $\mathrm{SCBH}$ support}

With the simulation disregarding the integration between withdrawals and waste water discharges (the method used in the state of Bahia), a very similar result for the quantitative potential water use index for the majority of stretches was found as presented in Figure 8. But, by analysing each stretch where there was an interference due to waste water discharge, an average decrease in the quantitative compromise indictor of $2.5 \%$ was verified, this being the alteration more evident in river segments with compromise from alert to critical. 
With the simulation disregarding the integration between withdrawals and waste water discharges, a similar result for the qualitative potential water use index for the majority of streams was also found, as is shown in Figure 9.

With the view to exemplify the relevance of the quali-quantitative integration related to the quantitative compromise, three stretches, of a tributary of the Paraguaçu River that have water surface withdrawal users and waste water discharge users were selected and the results verified from the simulations performed. Those stretches are identified in "AREA 2" in Figure 8 and can be viewed in Figure 10.

The results of the simulations made are presented in Table 7, being Iquant(A), the result of the quantitative index for the simulation integrating quantitative and qualitative analysis; Iquant $(B)$, the result of the quantitative index for the simulation considering only withdrawal users; DBOsim(A), the simulated DBO result for the simulation integrating qualitative and quantitative analysis; and, DBOsim(B), the simulated DBO result considering only waste water discharge users.

As presented in Table 7, stretches from AREA 2 have low quantitative compromises $(5.5 \% ; 4.2 \%$; and $2.7 \%)$ when SCBH is inputted with withdrawal and discharge data. When SCBH is only inputted with the water permit data for withdrawals, disregarding authorized waste water discharge users, the results for the quantitative compromise of the presented stretches increase, being, respectively: $97.2 \% ; 75.2 \%$; and $47 \%$.

Observing these results, it is possible to prove that waste water discharge increases the water availability of the stretch where it occurs and of the stretches downstream, since the flow discharged is summed with the available flow in the stretch for purposes of water permit. Thus, to adopt this alternative of analysis, it is necessary that the decision maker has data reliability, as the system becomes less restrictive by increasing local water availability. Data reliability can be effected with inspection campaigns after the deadline to implant the Waste water Treatment Plant and the beginning of the waste water discharge (term defined in the Water Permit Ordinances) and with frequent and extensive campaigns of quali-quantitative monitoring.

The stretches from AREA 2 have DBOsim values of $5.7 \mathrm{mg} / \mathrm{L} ; 4.5 \mathrm{mg} / \mathrm{L}$; and $3.2 \mathrm{mg} / \mathrm{L}$ when the $\mathrm{SCBH}$ is inputted with withdrawal and discharge data. The results for DBOsim of the indicated stretches show that there was practically no alteration in qualitative index when existing surface water withdrawal is considered, being, respectively: $5.5 \mathrm{mg} / \mathrm{L} ; 4.4 \mathrm{mg} / \mathrm{L}$; and $3.1 \mathrm{mg} / \mathrm{L}$.

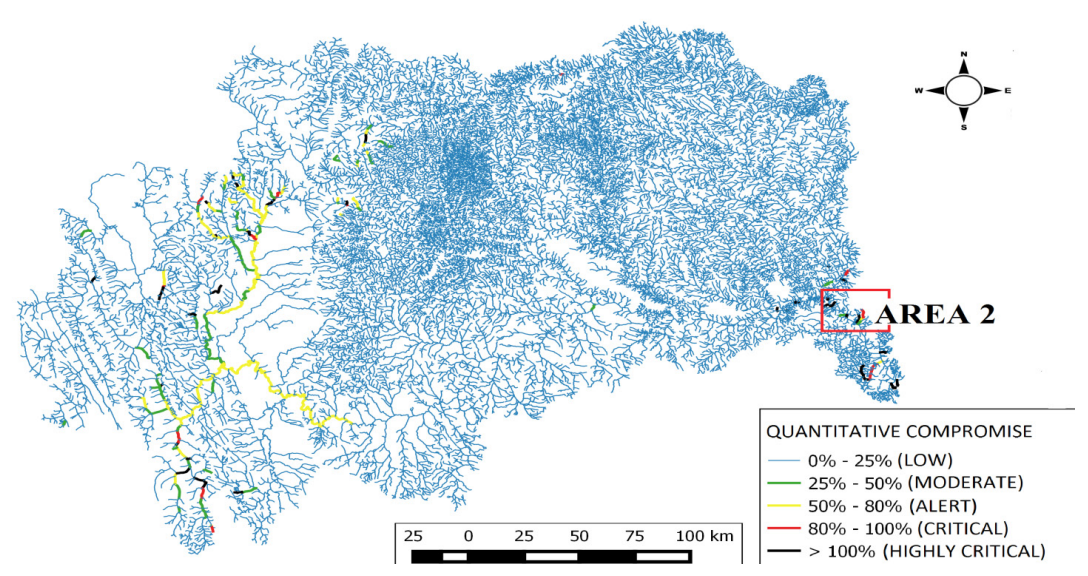

Figure 8. Quantitative potential water use index - considering only withdrawal users.

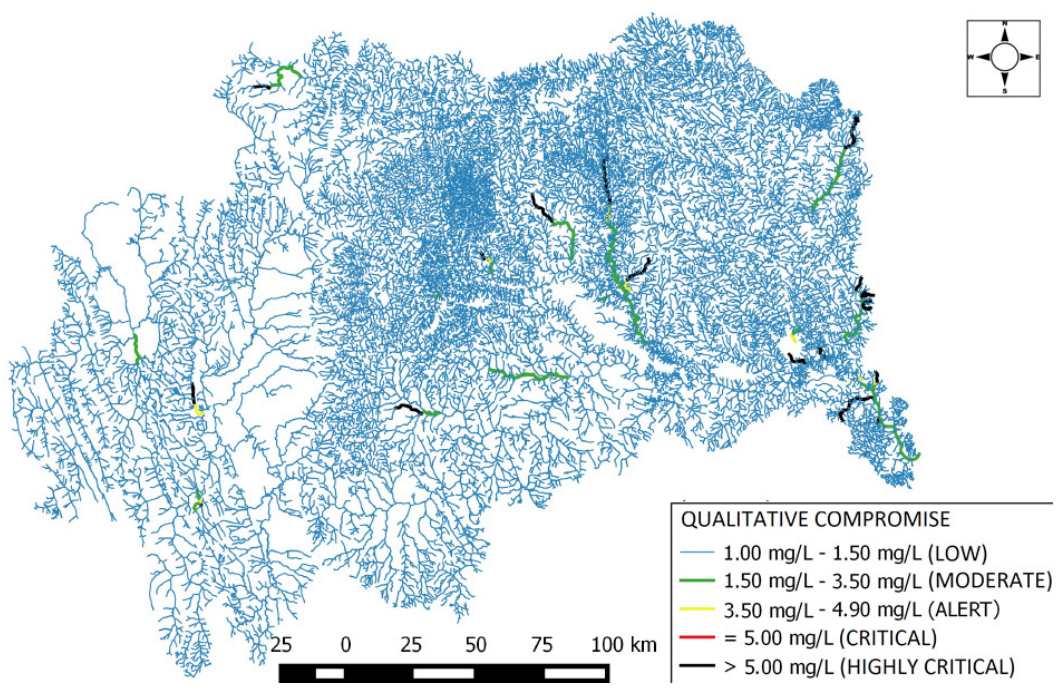

Figure 9. Qualitative potential water use index - considering only discharge users. 


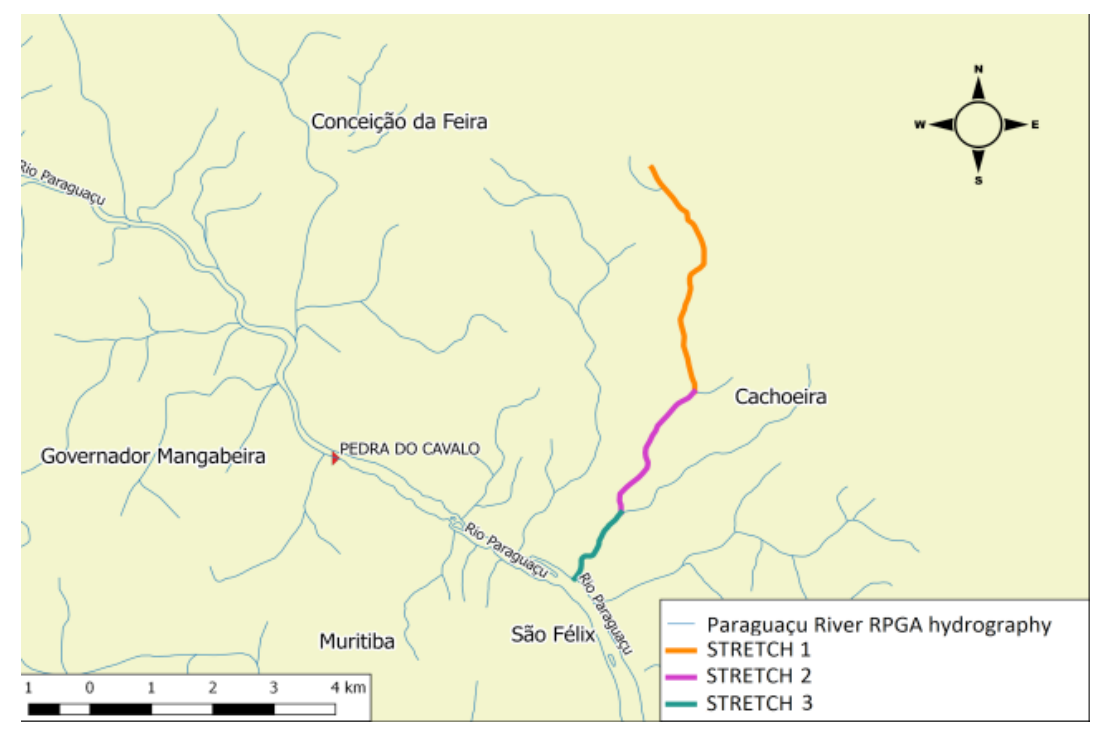

Figure 10. AREA 2 - Chosen area to exemplify the relevance of quali-quantitative integration.

Table 7. Simulation results for AREA 2.

\begin{tabular}{ccccc}
\hline STRETCH & Iquant(A) (\%) & Iquant(B) (\%) & DBOsim(A) (mg/L) & DBOsim(B) (mg/L) \\
\hline STRETCH 1 & 5.5 & 97.2 & 5.7 & 5.5 \\
STRETCH 2 & 4.2 & 75.2 & 4.5 & 4.4 \\
STRETCH 3 & 2.7 & 47.0 & 3.2 & 3.1 \\
\hline
\end{tabular}

Even verifying these results, it is known that surface water withdrawal can withdraw DBO load from the river, in the same proportion that it takes the local water availability of the stretch where it is placed and of the stretches downstream, as well as decreasing local water availability for waste water dilution.

This influence can be more or less significant, depending on the characteristics of the waste water discharged and the amount of withdrawal flow when compared to the discharged flow. With the BHRP diagnosis results, the influence of other water resources management instruments on the instrument of water permit is evident, because the results do not represent the local reality. Even though the SCBH methodology portrays progress regarding the SIGOs methodologies, starting to use it is not enough.

The success of the water permit instrument depends also on the data used as input in the system. A considerably greater amount of data and planning data (watershed plans and framework of water bodies in classes) of higher quality, as well as inspection and monitoring being required. Furthermore, it necessitates that SEIA integrate all of this information, making it available to aid in the decision-making process.

\section{CONCLUSIONS}

Comparing the applied methodologies in the present study case it was possible to conclude that:

- the methodology of equating the quali-quantitative water balance does not represent significant advance to the water resources management when there are limitations on the factors involved;
- it is fundamental that there be sufficient structure in order that, primarily, the instruments of framework of water bodies in classes, inspection and monitoring work can be integrated with the water permit, ensuring that the water balance simulation be as close as possible to reality;

- by developing the water balance analysis without considering the quali-quantitative interrelation to specific stretches where there are users of waste water discharge and surface water withdrawal, the availability of water is underestimated for the analysis of withdrawals on the stretch and it is overestimated for the analysis of waste water discharge. Thus, by considering the possibility of adopting a quali-quantitative methodology, the management board must consider the risks of oversizing the flow to be collected with the increment of waste water flow discharged.

It is noteworthy that, with the integration of analyses there is improvement in the quality of technical analysis, since the analyst user, decision maker, has a broader view about the stretch where the water permit is being evaluated.

However, for the integration methodology of analysis used by ANA, with the $\mathrm{SCBH}$, to be used there are requisites and limitations that must be observed to verify the feasibility of its application by a management board that desires to implant it.

This study also analysed the influence of other instruments of the Water Resources Policies on the water permit instrument, because from the results presented, it was concluded that, regardless of the methodology used for equating the water balance for purposes of granting permits, it is necessary that the entire water resources management system be well structured so that there is effectiveness in the application of procedure. 
The results represent a contribution to the water regulatory agencies, as the study presents comparison of methodologies used by them and reinforces the importance of structuring all water resources policy instruments in order to have effective control of water use.

\section{ACKNOWLEDGEMENTS}

The authors give thanks to the Environment, Water and Sanitation Master's Program (MAASA), to the Environment Department of the Polytechnic of the Federal University of Bahia (UFBA) and to CNPq for sponsoring the PQ scholarship of the fourth author.

\section{REFERENCES}

ANA - AGÊNCIA NACIONAL DE ÁGUAS. Manual de procedimentos técnicos e administrativos de outorga de direito de uso de recursos hidricos. Brasília, 2013. Available from: < http://arquivos.ana.gov.br/institucional/ sof/MANUALDEProcedimentos'TecnicoseAdministrativosde OUTORGAdeDireitodeUsodeRecursosHidricosdaANA.pdf>. Access on: 04 june 2016.

BAHIA. Governo do Estado. Superintendência de Recursos Hídricos do Estado da Bahia. PERH-BA: Plano Estadual de Recursos Hidricos. Relatório Final da Etapa 1: Diagnóstico e Regionalização. Salvador: Consórcio Magna, 2003. v. 1.

BAHIA. Governo do Estado. Superintendência de Recursos Hídricos do Estado da Bahia. Instrução Normativa no 01, de 27 de fevereiro de 2007. Dispõe sobre a emissão de outorga de direito de uso dos recursos hídricos de domínio do Estado da Bahia, assim como a sua renovação, ampliação, alteração, transferência, revisão, suspensão e extinção, e dá outras providências. Diário Oficial do Estado, Salvador, 27 fev. 2007a.

BAHIA. Governo do Estado. Superintendência de Recursos Hídricos do Estado da Bahia. Instrução Normativa no ${ }^{\circ}$ 03, de 08 de novembro de 2007. Dispõe sobre critérios técnicos referentes à outorga para fins de diluição, transporte ou disposição final de esgotos domésticos em corpos de água de domínio do Estado da Bahia. Diário Oficial do Estado, Salvador, 14 nov. 2007b. Ano XCII, n. 19.55.

BAHIA. Lei no 11.612 de 08 de outubro de 2009. Dispõe sobre a Política Estadual de Recursos Hídricos, o Sistema Estadual de Gerenciamento de Recursos Hídricos, e dá outras providências. Diário Oficial do Estado, Salvador, BA, 11 out. 2009.

BAHIA. Lei no 12.212 de 04 de maio de 2011. Modifica a estrutura organizacional e de cargos em comissão da Administração Pública do Poder Executivo Estadual, e dá outras providências. Diário Oficial do Estado, Salvador, BA, 5 maio 2011.

BEZERRA, D. D. S.; MACHADO, K. D. A.; GOMES, A. C. Outorga de direito de uso da água e a política maranhense de recursos hídricos. Revista Direito Ambiental e Sociedade, v. 3, n. 2, p. 227-249, 2015.

BRASIL. Constituição da República do Brasil de 1988. Brasília, DF, 1988.

BRASIL. Lei no 9.433, de 8 de janeiro de 1997. Institui a Política Nacional de Recursos Hídricos, cria o Sistema Nacional de Gerenciamento de Recursos Hídricos, regulamenta o inciso XIX do art. 21 da Constituição Federal, e altera o art. $1^{\circ}$ da Lei no 8.001 , de 13 de março de 1990, que modificou a Lei no 7.990, de 28 de dezembro de 1989. Diário Oficial [da] República Federativa do Brasil, Brasília, DF, 8 jan. 1997.

BRASIL. Conselho Nacional do Meio Ambiente. (2005). Resolução $n^{\circ} 357$, de 17 de março de 2005. Dispõe sobre a classificação dos corpos de água e diretrizes ambientais para o seu enquadramento, bem como estabelece as condições e padrões de lançamento de efluentes, e dá outras providências. Diário Oficial [da] República Federativa do Brasil, Brasília, DF, 18 mar. 2005.

COLLISCHONN, B. Sistema de apoio à decisão para outorga de direito de uso de recursos hídricos. 2014. 177 f. Tese (Doutorado em Engenharia de Recursos Hídricos e Saneamento Ambiental) - Instituto de Pesquisas Hidráulicas, Universidade Federal do Rio Grande do Sul, Porto Alegre, 2014.

COLLISCHONN, B.; LOPES, A. V. (2008) Sistema de controle de balanço hídrico para apoio à outorga na bacia do São Francisco. In: ENCONTRO NACIONAL DE HIDROINFORMÁTICA, 1., 2008, Fortaleza. Anais... Fortaleza: Universidade de Fortaleza, 2008.

CONAMA - CONSELHO NACIONAL DE MEIO AMBIENTE. Resolução no 357 de 17 de março de 2005. Dispõe sobre a classificação dos corpos de água e diretrizes ambientais para o seu enquadramento, bem como estabelece as condições e padrões de lançamento de efluentes. Diário Oficial [da] República Federativa do Brasil, Brasília, DF, 18 mar. 2005.

CONAMA - CONSELHO NACIONAL DE MEIO AMBIENTE. Resolução $n^{\circ} 430$ de 13 de maio de 2011. Dispõe sobre as condições e padrões de lançamento de efluentes, complementa e altera a Resolução no 357 de 17 de março de 2005, do Conselho Nacional do Meio Ambiente. Diário Oficial [da] República Federativa do Brasil, Brasília, DF, 16 maio 2011.

CONERH - CONSELHO ESTADUAL DE RECURSOS HÍDRICOS. Resolução no 79 de 18 de novembro de 2010. Aprova o Enquadramento Transitório da Bacia do Riacho da Panela, do Riacho Principal, Rio Chapadinha, Rio Paraguaçu (jusante da Barragem de Pedra do Cavalo). Diário Oficial do Estado, Salvador, BA, 23 nov. 2010.

GENZ, F.; TANAJURA, C. A. S.; ARAÚJO, H. A. Impacto das mudanças climáticas nas vazões dos rios Pojuca, Paraguaçu e Grande: cenários de 2070 a 2100. Revista Babia Análise \& Dados, v. 21, n. 4 , p. $807-823,2011$. 
IBGE - INSTITUTO BRASILEIRO DE GEOGRAFIA E ESTATÍSTICA. (2010). Sinopse do Censo Demográfico de 2010. Rio de Janeiro, 2010. Available from: <http://www.censo2010.ibge.gov. br/sinopse $/$ index.php?uf $=29 \& d a d o s=1>$. Access on: 06 july 2016.

KELMAN, J. Gerenciamento de recursos hídricos: parte 1: outorga. In: SIMPÓSIO BRASILEIRO DE RECURSOS HÍDRICOS, 12., 1997, Vitória. Anais... São Paulo: ABRH, 1997. p. 123-128.

LEMOS, R. S.; MAGALHÃES JUNIOR, A. P. Reflexões sobre os critérios de cálculo de vazões outorgáveis em áreas de conflito do estado de Minas Gerais: o caso da Bacia do Ribeirão Ribeiro Bonito. Revista Espinhaço, v. 4, n. 2, p. 4-12, 2015.

PESSOA, M. M. E. P.; KAYSER, R. B.; COLLISCHONN, W. Integração do Modelo Hidrológico para Grandes Bacias MGB IPH e Sistemas de Informação Geográfica para suporte à decisão de outorga de direito de uso da água. REGA: Revista de Gestão de Água da América Latina, v. 9, n. 2, p. 21-33, 2012.

PINHEIRO, R.B.; MONTENEGRO, S.M.G.L.; SILVA, S.R., MEDEIROS, Y.D.P.; AURELIANO, J.T. (2013) Outorga para lançamento de efluentes: uma metodologia de apoio à Gestão de Recursos Hídricos. Revista Brasileira de Recursos Hídricos, v. 18, n. 4, p. 55-65, 2013.

RODRIGUES, M. V. S.; AQUINO, M. D.; THOMAZ, A. C. F. Análise por envoltória de dados utilizados para medir o desempenho relativo da cobrança pelo uso da água nas Bacias Hidrográficas do Estado do Ceará. Revista de Gestão de Água da América Latina, v. 12 , n. 1, p. 15-29, 2015.

SANTANA, A. G.; CARDOSO, E. R.; SILVA, F. F.; PEREIRA, J. S. Metodologia para Controle das Outorgas de Direito de Uso da Água em Bacias Hidrográficas. In: SIMPÓSIO DE RECURSOS HÍDRICOS DO NORDESTE, 6., 2002, Maceió. Anais... São Paulo: ABRH, 2002. p. 343-348.

SILVA, B. M. B.; SILVA, D. D.; MOREIRA, M. C. Índices para a gestão e planejamento de recursos hídricos na bacia do rio Paraopeba, Estado de Minas Gerais. Revista Ambiente \& Água, v. 10, n. 3, p. 685-697, 2015.

SILVA, F.F.; CARDOSO, E. R.; SANTANA, A. G.; PEREIRA, J. S.; CORTIZO, C. S.; CUNHA, R. G. L.; RIBEIRO, C. A. O.
Sistema de Gerenciamento de controle de outorga - SIGO: uma aplicação na bacia do rio Paraguaçu, Bahia. In: SIMPÓSIO DE RECURSOS HÍDRICOS DA AMAZÔNIA - SRH, 1., 2003, Manaus. Anais... [S.l.]: [s.n.], 2003.

SOUZA, J. S.; MORAES, B. S. Análise das políticas públicas implementadas para a Gestão dos Recursos Hídricos no Brasil. Ciência e Natura, v. 38, n. 2, p. 913-919, 2016. http://dx.doi. org/10.5902/2179460X21896.

TEIXEIRA, A. A. Ottocodificaşão estendida e inteligência hidrográfica em banco de dados geográficos. 2012. 425 f. Tese (Doutorado em Geociências Aplicadas) - Universidade de Brasília, Brasília, 2012.

VEIGA, L. B. E.; MAGRINI, A. The brazilian water resources management fifteen years of success and chanllenges. Water Resources Management, v. 27, n. 7, p. 2287-2302, 2013. http://dx.doi. org/10.1007/s11269-013-0288-1.

WESSLING, C. S. Avaliação comparativa entre os procedimentos técnicos, legais e administrativos de outorga para lancamento de efluentes em rios adotados no Brasile na Alemanha. 2011. 186 f. Dissertação (Mestrado Profissional em Meio Ambiente Urbano e Industrial) - Setor de Tecnologia, Universidade Federal do Paraná, Curitiba, 2011.

WURBS, R. A. Water rights in Texas. Journal of Water Resources Planning and Management, v. 121, n. 6, p. 447-454, 1995. http:// dx.doi.org/10.1061/(ASCE)0733-9496(1995)121:6(447).

\section{Authors contributions}

Gisele Oliveira Mota da Silva: Work conception, simulation executions, data acquirement and treatment, discussion and writing of the paper.

Yvonilde Dantas Pinto Medeiros: Conception, discussion, data analysis, revision and writing of the paper.

Andrea Sousa Fontes: Conception, discussion, data analysis, revision and writing of the paper.

Suzana Maria Gico Lima Montenegro: Conception, discussion, data analysis, revision and writing of the paper. 